This PDF is a selection from a published volume from the National Bureau of Economic Research

Volume Title: The Structure of Wages: An International Comparison

Volume Author/Editor: Edward P. Lazear and Kathryn L. Shaw, editors

Volume Publisher: University of Chicago Press

Volume ISBN: 0-226-47050-4; 978-0-226-47050-4

Volume URL: http://www.nber.org/books/laze08-1

Conference Date:

Publication Date: January 2009

Chapter Title: Wage Structure and Labor Mobility in the United States

Chapter Author: John Abowd, John Haltiwanger, Julia Lane

Chapter URL: http://www.nber.org/chapters/c2367

Chapter pages in book: (p. 81 - 100) 


\title{
Wage Structure and Labor Mobility in the United States
}

\author{
John M. Abowd, John Haltiwanger, and Julia Lane
}

\subsection{Introduction}

The new availability of linked employer-employee data in the United States has led to an explosion of interest in research about the outcomes of the labor market interactions of firms and workers. The long history of the examination of worker-based data has revealed the fundamental heterogeneity of worker outcomes, even with rich information on worker characteristics. Similar, but more recent, examination of firm-based data has revealed startling heterogeneity of firm outcomes, despite similarly rich information on industry and firm structure. One of the most interesting, although perhaps not surprising, results from the very recent access to linked

John M. Abowd is the Edmund Ezra Day Professor of Industrial and Labor Relations at Cornell University, and a research associate of the National Bureau of Economic Research. John Haltiwanger is a professor of economics at the University of Maryland, and a research associate of the National Bureau of Economic Research. Julia Lane is program director of the Science of Science and Innovation Policy (SciSIP) at the National Science Foundation.

This document reports the results of research and analysis undertaken by the U.S. Census Bureau staff. This document is released to inform interested parties of ongoing research and to encourage discussion. This research is a part of the U.S. Census Bureau's Longitudinal Employer-Household Dynamics Program (LEHD), which is partially supported by the National Science Foundation Grants SES-9978093 and SES-0427889 to Cornell University (Cornell Institute for Social and Economic Research), the National Institute on Aging Grant R01 AG018854, and the Alfred P. Sloan Foundation. The views expressed on technical issues are those of the authors and not necessarily those of the U.S. Census Bureau, its program sponsors, or data providers. Some or all of the data used in this paper are confidential data from the LEHD Program. The U.S. Census Bureau supports external researchers' use of these data through the Research Data Centers (see http://www.ces.census.gov). For other questions regarding the data, please contact Jeremy S. Wu, Assistant Division Chief, U.S. Census Bureau, LEHD Program, Center for Economic Studies, 4600 Silver Hill Road, Suitland, MD 20233, USA (see Jeremy.S.Wu@census.gov; http://lehd.ces.census.gov). 
employer-employee data has been that researchers can explain much more when they have information on both sides of the labor market, rather than one or the other.

In this chapter, we exploit this access to examine the sources of variation in two core outcomes of interest to economists - the earnings distribution and mobility patterns. We particularly focus on the contribution of within and between employer variation in these outcomes. In what follows, we provide a brief literature review and institutional background. We also briefly describe the new database infrastructure, as well as present some basic statistics about the structure of wages within and between firms as well as job mobility patterns.

\subsection{Review of the Literature}

The increased earnings inequality in the United States that was so evident in the 1980s and early 1990s has not been so apparent in the mid- to late 1990s (Card and DiNardo 2002). Although the consensus in the literature is that skill-biased technical change was the primary driver behind the increased inequality (see, e.g., Acemoglou 2002), Card and DiNardo cast doubt on this because the mid- to late 1990s has been characterized by enormous technological advances without commensurate increases in inequality.

Rising wage inequality in the 1980s in the United States has been attributed in part to increasing returns to education. However, increases in wage dispersion among similar workers suggest that returns to unobservable skill or individual life chances have also increased (Katz and Autor 1999; Levy and Murnane 1992). Despite the overall increase in wage inequality in the United States since the late 1970s, changes in wage structures vary widely across states and across industries. Increases in wage inequality across states are highly correlated with shifts in industrial composition, particularly the decline in manufacturing (Bernard and Jensen 1998).

Changes in the distribution of wages may partly reflect changes on the firm (or demand) side of the labor market. Numerous studies have established the role of firm effects on wages and on wage inequality. Important early work in this area is Groshen (1991), who explored the role of demand side effects from the Bureau of Labor Statistics (BLS) Occupational Wage Surveys. She found that establishment wage differentials account for a substantial fraction of the variation in wages. Related work has examined the establishment and firm characteristics that matter. For example, firm size is an important determinant of wages, and wage inequality has increased both among and within manufacturing plants (Davis and Haltiwanger 1996, 1991). Differences in industry employment shares across states partially explain differences in wage inequality across states (Bernard and Jensen 1998). High-wage firms, or firms that seem to pay a wage premium 
or markup, and high-wage workers, or those who earn a premium, can be identified (Abowd, Kramarz, and Margolis 1999). Changes in the allocation of workers to jobs could affect the wage distribution; if high-wage workers are more likely to sort toward firms that pay a high wage premium and low-wage workers more likely to sort toward firms that pay workers a discount, then the earnings distribution will become more unequal.

Indeed, earlier work (Andersson, Holzer, and Lane 2005) that focused on the low-wage labor market found that where low-wage workers work can have a major impact on their earnings and, indeed, that the process by which workers are matched to firms in the low-wage labor market has large and important effects on the outcomes we observe for these workers. This very detailed analysis also found that there is considerable mobility into and out of low earnings categories over time, that the characteristics of employers are highly correlated with earnings and with transitions out of low earnings status, and that the characteristics and behaviors of particular firms affect opportunities for low earners.

Work by Davis, Faberman, and Haltiwanger (2006) has directly examined the way in which changes in workforce composition, firm entry and exit, and job reallocation affect industry-specific earnings distributions between 1998 and 2003. They found that worker entry and exit had very little impact on changes in the earnings distributions: despite the ample opportunities for firms to change their workforce composition, industry workforces remained, by and large, very similar, and earnings gains due to experience tended to be higher at the lower end of the distribution. This does not lend credence to the notion that individual firms are changing their production technologies in a way that is biased toward skill. Changes in observable characteristics, which mainly involved the aging of the workforce within each industry, tended to shift the earnings distributions of all industries to the right. The net impact of firm entry and exit is to reduce the dispersion of earnings for all industries. Sorting of workers based on the "human capital" measures over time tended to increase the dispersion of industry earnings distributions between 1992 and 2003. This is consistent with the idea that the driving force of economic change is the entry and exit of firms and can be linked to the selection of new technologies and the associated workforce by new firms. Their results suggest that the underlying dynamics of earnings inequality are complex and are due to factors that cannot be measured in standard cross-sectional data.

\subsection{Background}

The United States has had lower unemployment than most Organization for Economic Cooperation and Development (OECD) countries in the 1980s and 1990s: below 7 percent for almost all of the past decade. Although there was weak growth and a mild recession in the early 1990s, the 
Table 2.1

Macroeconomic conditions

\begin{tabular}{lccccccccccc}
\hline & 1990 & 1991 & 1992 & 1993 & 1994 & 1995 & 1996 & 1997 & 1998 & 1999 & 2000 \\
\hline $\begin{array}{l}\text { Unemployment } \\
\quad \text { rate }\end{array}$ & 5.6 & 6.8 & 7.5 & 6.9 & 6.1 & 5.6 & 5.4 & 4.9 & 4.5 & 4.2 & 4.0 \\
$\begin{array}{l}\text { Change in GDP } \\
\quad \begin{array}{l}\text { year } \\
\quad \text { year }\end{array}\end{array}$ & 0.5 & 0.9 & 4.0 & 2.6 & 4.1 & 2.2 & 4.1 & 4.3 & 4.8 & 4.3 & 2.3 \\
$\quad 1.6$ & 0.7 & 2.5 & 3.3 & 3.3 & 3.1 & 3.1 & 4.2 & 4.6 & 4.6 & 3.3 \\
$\quad$ year & 2.8 & 2.4 & 2.4 & 2.1 & 2.4 & 2.7 & 3.4 & 3.4 & 3.9 & 3.9 & 4.0 \\
\hline
\end{tabular}

mid- to late 1990s were characterized by strong growth - between 2 and 5 percent in the two years selected for this chapter. See table 2.1 for a summary of the macroeconomic conditions in the United States during this time period.

A number of labor market changes took place during the period. First, U.S. unionization rates dropped markedly from 20.1 percent for all workers in 1983 to 12.9 percent in 2003. The decline is even more in the private sector, where unionization is now at 8.2 percent; public-sector unionization rates are around 37 percent (Card, Kramarz, and Lemieux 1998). Several researchers (DiNardo, Fortin, and Lemieux 1996; Card, Kramarz, and Lemieux 1998) find that this decline explains at least part of the increase in the variance of $\log$ wages.

Second, there has been substantial immigration. More than 15 percent of the workforce is foreign born, and immigrants account for more than half of the growth in the workforce in the 1990s. These workers are disproportionately employed in jobs that require little education - particularly the 40 percent who came from Mexico and Central America (Congressional Budget Office 2005).

Third, the growth in the rate of labor force participation slowed substantially from earlier decades: from a 3.6 percent annual increase in the 1970 s to 2.8 percent in the 1980 s to a scant .6 percent rate of increase in the $1990 \mathrm{~s}$, although this is due to complex offsetting factors. On the one hand, the substantial increase in the prime-age twenty-five to fifty-four-year-old population (from approximately 50 percent of the over-sixteen-yearold population in 1975 to nearly 58 percent in 1996), acted to increase participation rates. In addition, the flat participation rates of never-married mothers increased dramatically in the mid 1990s after the passage of Personal Responsibility and Worker Opportunity Reform Act of 1996 (PRWORA) and the expansion of the Earned Income Tax Credit program (EITC). On the other, male labor force participation rates continued to decline, and the increases in the participation of married mothers, which had had so much impact in the 1970s and 1980s, slowed substantially in the 1990s (Juhn and Potter 2006).

Finally, the real value of the minimum wage declined systemically over 
the period (see Blackburn, Bloom, and Freeman 1990; DiNardo, Fortin, and Lemieux 1996; Lee 1999).

These changes were accompanied by rising wage inequality in 1980s and 1990s. The general characterization of this increase is its "fractal" nature: that a large component of the level and growth in dispersion is withingroup (Levy and Murnane 1992; Moffitt 1990; Burtless 1990). In addition, the college-high school premium increased much less in the 1990s than in the 1980s despite the fact that relative supply kept increasing at the same rate (see Card and DiNardo 2002; Beaudry and Green 2003a; and Lemieux 2004).

The United States example is particularly instructive in that a great deal of research has been devoted to decomposing the earnings distribution into observed and unobserved factors by Abowd and coauthors (see Abowd, Lengermann, and McKinney [2002] for the most recent summary). Briefly, using data and methodology described in detail in the following, Abowd, Lengermann, and McKinney approach permits the decomposition of the wage rate into time varying characteristics, person effect (unobserved and measurable), firm effect, and residual. The results of this decomposition using the data used in the basic statistics discussed later in the chapter are reported in table 2.2. Unlike other versions of this table (e.g., Abowd, Lengermann, and McKinney), this one has been weighted to be representative of the U.S. workforce in 1990 to 2000. Table 2.2 also presents simple correlations of the wage components. By construction, the wage residual is orthogonal to all other wage components.

Intuitively, the person effects, which include some factors that are often observable to the statistician, such as years of education and sex; and some factors that are often not, such as innate ability, people skills, problem solving skills, perseverance, family background, and educational quality, can be thought of as their human capital; the firm effects can be thought of as the pay premium as a result of unionization, rent sharing, or compensating differentials.

There are several striking results to be found from an examination of the table. Most obviously, person and firm heterogeneity are both highly correlated with annualized wages, despite only being mildly positively correlated with each other. In addition, the correlation between time varying individual characteristics and annualized wages, while positive, is smaller than the correlation between either person or firm effects and wages. It is also interesting that both the observed constant person effects and the unobserved person effects are important components of the variation in log wages across individuals.

Abowd, Lengermann, and McKinney (2002) have also examined changes in human capital over time. They find a pronounced right shift in the overall distribution of human capital over the five year period of 1992 to 1997. This is due to increased labor market experience of the existing 
Table 2.2

Decomposition of the real wage rate standard deviations and correlations of components (weighted)

\begin{tabular}{|c|c|c|c|c|c|c|c|c|}
\hline & $\begin{array}{l}\text { Standard } \\
\text { deviation }\end{array}$ & $\begin{array}{l}\text { Log } \\
\text { real } \\
\text { wage }\end{array}$ & $\begin{array}{c}\text { Time } \\
\text { varying } \\
\text { characteristics }\end{array}$ & $\begin{array}{c}\text { Person } \\
\text { effect }\end{array}$ & $\begin{array}{l}\text { Unobserved } \\
\text { person } \\
\text { effect }\end{array}$ & $\begin{array}{c}\text { Constant } \\
\text { person } \\
\text { characteristics }\end{array}$ & $\begin{array}{l}\text { Firm } \\
\text { effect }\end{array}$ & Residual \\
\hline Log real wage & 1.914 & 1.000 & 0.732 & 0.225 & 0.216 & 0.483 & 0.470 & 0.394 \\
\hline \multicolumn{9}{|l|}{ Time varying } \\
\hline characteristics & 1.656 & 0.732 & 1.000 & 0.347 & 0.200 & 0.627 & 0.141 & -0.008 \\
\hline Person effect & 1.502 & 0.225 & 0.347 & 1.000 & 0.914 & -0.513 & 0.074 & 0.001 \\
\hline $\begin{array}{l}\text { Unobserved person } \\
\text { effect }\end{array}$ & 1.417 & 0.216 & 0.200 & 0.914 & 1.000 & -0.576 & 0.059 & 0.001 \\
\hline $\begin{array}{l}\text { Constant person } \\
\text { characteristics }\end{array}$ & 1.808 & 0.483 & 0.627 & -0.513 & -0.576 & 1.000 & 0.068 & -0.009 \\
\hline Firm effect & 0.798 & 0.470 & 0.141 & 0.074 & 0.059 & 0.068 & 1.000 & 0.000 \\
\hline Residual & 0.769 & 0.394 & -0.008 & 0.001 & 0.001 & -0.009 & 0.000 & 1.000 \\
\hline
\end{tabular}

workforce, offset slightly by a net reduction in human capital from entry and exit. Their analysis notes that these changes took place despite the fact that the overall wage distribution remained largely unchanged over the same period, largely reflecting the tendency of labor force entrants to sort into firms with below-average internal wages and of continuers to sort into firms with above-average internal wages, thereby exacerbating preexisting wage differences.

Abowd, Lengermann, and McKinney (2002) also examined the human capital distributions for firms in both 1992 and 1997 and found a pronounced tendency for firms to employ workers at the ends of the human capital distribution rather than the middle - even within firms in the same industry. Between 1992 and 1997, between-firm variation in the employment shares of low-skilled workers declined, while the average firm in virtually every industry upskilled considerably. Employment shares in the bottom two skill deciles fell by 7.7 percent and 5.2 percent, respectively, but increased by 6 percent in each of the two highest skill deciles.

\subsection{The Structure of the LEHD Program Data}

The LEHD database infrastructure is complex. The core integration records are state unemployment insurance (UI) wage records (which are described in detail elsewhere). The integration of the business and demographic data by means of these records, which takes place under strict confidentiality protection protocols, ${ }^{1}$ can be visualized by examining figure

1. The data are anonymized before use and may only be used for statistical purposes and for approved projects by Census Bureau employees. In addition, the data are protected by Title 13 of the U.S. Code: employees who disclose the identity of an individual or business are subject to a penalty of five years in jail, a $\$ 250,000$ fine, or both. 


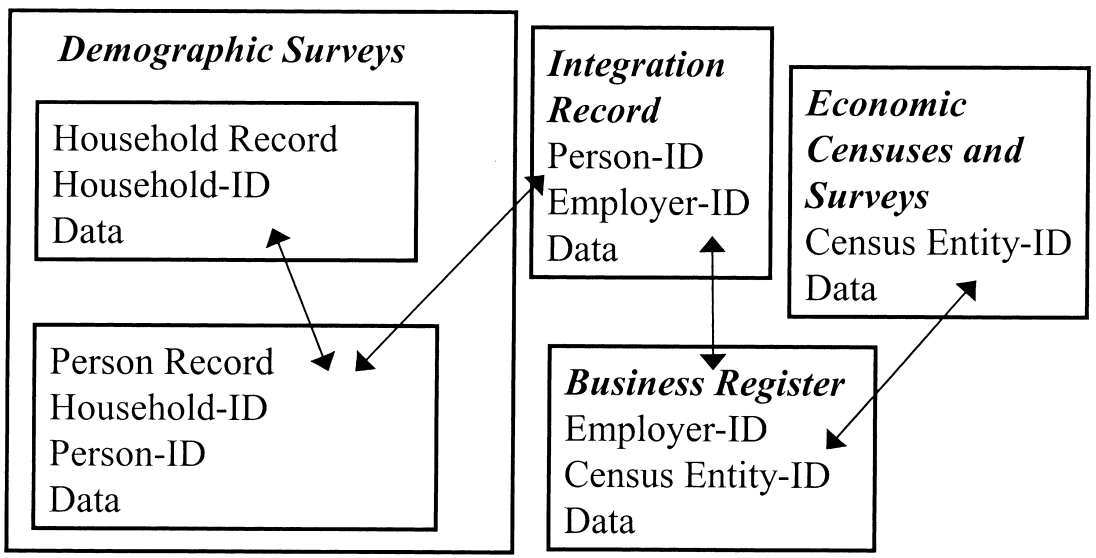

Fig. 2.1 The LEHD program

2.1. These UI records, from now more than forty-eight partner states representing more than 95 percent of U.S. employment, consist of quarterly reports filed by employers every quarter for each individual in covered employment. These records permit the construction of a database that provides longitudinal information on workers, firms, and the match between the two. The coverage is roughly 96 percent of private nonfarm wage and salary employment; the coverage of agricultural and federal government employment is less comprehensive. Self-employed individuals and independent contractors are also not covered. ${ }^{2}$ Although the administrative records themselves are subject to some error, staff at the LEHD program has invested substantial resources in cleaning the records and making them internally consistent. ${ }^{3}$

The U.S. Census Bureau information that is integrated into this infrastructure backbone consists of basic demographic information: date of birth, place of birth, sex, and a crude measure of race and ethnicity for almost all workers in the data set - the nonmatch rate is about 4 percent. Other demographic survey data are integrated if the use is permitted under Title 13 of the U.S. Code. While the Census Business Register is the core integration file for business data, other business surveys are also included and integrated (again if the use is permitted under Title 13 of U.S. Codemore information on the microbusiness data integrated can be found at the Center for Economic Studies Web site at http://www.ces.census.gov). To sum up, for the universe of employers and employees, the range of infor-

2. See David Stevens (2002). The LEHD program is currently working on using administrative data to track self-employment.

3. The approach is described in John Abowd and Lars Vilhuber (2005). 
mation is limited to earnings histories, earnings, employment matches, and basic information such as gender and age of the worker and the location and industry of the business. However, for subsamples of records integrated with Census demographic and business data, additional detailed information is available.

In the current chapter, we present some summary statistics of the structure of wages within and between firms as well as patterns of worker turnover. There are some conceptual issues that need to be made clear. Although we typically refer to the employer as a "firm," the actual reporting unit in the data is an administrative, rather than an economic entity, as the filing unit reflects an employer identification number, rather than a specific firm. The distinction is immaterial for about 70 percent of workers, who work for a single establishment employer-but those who work for a multiple establishment employer, the use of the term "firm" in this book is less well-defined. In addition, no occupation information is available. We observe a "job" as an employer-employee match, and we can only observe internal earnings mobility - not occupational mobility.

An important issue to address is that of earnings. According to the $B L S$ Handbook of Methods (1997), UI wage records measure "gross wages and salaries, bonuses, stock options, tips, and other gratuities, and the value of meals and lodging, where supplied." They do not include Old-Age, Survivors, and Disability Insurance (OASDI), health insurance, workers compensation, unemployment insurance, and private pension and welfare funds. In addition, because neither hours nor weeks worked are available on the data, there is no information on hourly or weekly earnings. Consequently, low earnings in a given year (or quarter) can be due to low hourly wages, low hours, or both. Thus, some industries, like retail trade, will show up as low earnings industries at least partly because so much of the work in that industry is part time. Note that hours or weeks worked are typically not reported by employers.

In this chapter, the dependent variable is based on the annualized fullyear, full-time wage rate developed in Abowd, Lengermann, and McKinney (2002). It is, essentially, the sum of full-quarter income for four consecutive quarters over the calendar year. When full-quarter income is missing, it is estimated based on the expected full-quarter income for that quarter given the pattern of employment in the six-quarter window that includes the last quarter from the previous year, the four quarters of the current year, and the first quarter of the next year. We derived monthly income by dividing the annualized measure by 12 , and deflated it by the CPI-U (base $1990=1.00$ ). Only the observation for the dominant employer (the one with whom the individual had the largest earnings [not wage rate] in a given year). Only full-time employees are used (based on the first implicate of the full-time imputation).

A change in the monthly wage rate is computed for individuals with two 
consecutive years of full-time employment. The change in the wage rate is $w(t)-w(t-1)$. Only those observations present in $t-1$ enter the change tables. The weight used is for period $t$. In computing entry, we define individuals as "entrant" in year $t$ if this year's dominant employer is different from last year's. Similarly, an individual is defined as an "exiter" in year $t$ if this year's dominant employer is different from next year's.

Finally, in the results we reported in table 2.2, we used this data to estimate measures of individual and firm fixed effects, following the methodology described in Abowd, Lengermann, and McKinney (2002).

$$
\ln w_{i t}=\theta_{i}+\psi_{J(i, t)}+x_{i t} \beta+\varepsilon_{i t},
$$

where the dependent variable is the log wage rate of an individual $i$ working for employer $j$ at time $t$, and the function $J(i, t)$ indicates the employer $j$ of individual $i$ at date $t$. The first component of equation (1) is the timeinvariant person effect, the second component is the time-invariant firm effect, the third component is the contribution of time varying observable individual characteristics, and the fourth component is the statistical residual, orthogonal to all other effects in the model. The econometric methodology and estimates of human capital used in this chapter are discussed and described in detail in Abowd, Lengermann, and McKinney (2002). ${ }^{4}$

More complete details of the database used in this chapter are provided in appendix A. For the current chapter, we use a limited number of states for the years 1993 and 1998. However, as described in appendix B, we have developed weights so that the statistics here can be interpreted as nationally representative.

\subsection{Analysis}

The key purpose of this chapter is to describe wage structure and individual mobility within and across firms over the period in question. The first panel of table 2.3 provides the individual analysis by describing the distribution of real monthly wage rates and log real monthly wage rates for individuals - the summary statistics include the average, standard deviation, and 90th and 10th percentiles wages in that distribution. ${ }^{5}$

The first thing to note is that the entire distribution of earnings shifted to the right, as already noted by Abowd, Lengermann, and McKinney (2002): average wages increased over the period, as did the wages for workers at the top and bottom end of the distribution (the 90th, 75th, 25th, and 10th percentiles). It is also clear that the dispersion of earnings across workers is enormous. The standard deviation of log earnings is about 80

\footnotetext{
4. Recent research has extended this type of analysis to permit a mixed effects specification - see Abowd, Stephens, and Vilhuber (forthcoming).

5. An individual is included in the analysis if that person had a dominant employer in 1993 or 1998 and worked full time at that employer.
} 
Table 2.3

Structure of wages within and between firms (US\$1990)

\begin{tabular}{|c|c|c|c|c|}
\hline & \multicolumn{2}{|c|}{ Monthly full-time wages } & \multicolumn{2}{|c|}{ Log monthly wages } \\
\hline & 1993 & 1998 & 1993 & 1998 \\
\hline Average wage ${ }^{\mathrm{a}}$ & 3,074 & 3,253 & 7.6848 & 7.7323 \\
\hline $\mathrm{SD}$ & 4,015 & 4,230 & 0.81 & 0.82 \\
\hline 90th percentile & 5,555 & 5,925 & 8.6225 & 8.687 \\
\hline 75th percentile & 3,671 & 3,774 & 8.2083 & 8.2359 \\
\hline 25 th percentile & 1,319 & 1,389 & 7.1847 & 7.236 \\
\hline 10th percentile & 798 & 855 & 6.6824 & 6.7513 \\
\hline No. of workers & $26,403,031$ & $40,110,897$ & $26,403,031$ & $40,110,897$ \\
\hline \multicolumn{5}{|l|}{ Average of firm average } \\
\hline wage $^{\mathrm{b}}$ & 2,819 & 3,020 & 7.6111 & 7.6639 \\
\hline $\mathrm{SD}$ & 1,758 & 2,051 & 0.4968 & 0.5157 \\
\hline 90th percentile & 4,649 & 5,070 & 8.228 & 8.304 \\
\hline 75th percentile & 3,464 & 3,645 & 7.956 & 7.9988 \\
\hline 25 th percentile & 1,719 & 1,791 & 7.2591 & 7.3018 \\
\hline 10th percentile & 1,284 & 1,336 & 6.9757 & 7.0129 \\
\hline No. of firms & 132,659 & 202,528 & 132,659 & 202,528 \\
\hline Average of SD of wage ${ }^{b}$ & 2,280 & 2,434 & 0.5923 & 0.5966 \\
\hline $\mathrm{SD}$ & 2,354 & 2,452 & 0.1708 & 0.1741 \\
\hline 90th percentile & 4,403 & 4,888 & 0.8038 & 0.8132 \\
\hline 75th percentile & 2,595 & 2,848 & 0.6815 & 0.6866 \\
\hline 25 th percentile & 1,030 & 1,062 & 0.48 & 0.4813 \\
\hline 10th percentile & 711 & 732 & 0.402 & 0.4043 \\
\hline No. of firms & 132,659 & 202,528 & 132,659 & 202,528 \\
\hline \multicolumn{5}{|l|}{ Average coefficient of } \\
\hline variation of wages ${ }^{b}$ & 0.75 & 0.75 & 0.0782 & 0.0783 \\
\hline SD & 0.39 & 0.37 & 0.024 & 0.024 \\
\hline 90th percentile & 1.2 & 1.2 & 0.1079 & 0.1082 \\
\hline 75th percentile & 0.87 & 0.88 & 0.0904 & 0.0903 \\
\hline 25 th percentile & 0.52 & 0.52 & 0.0626 & 0.0624 \\
\hline 10th percentile & 0.42 & 0.42 & 0.0521 & 0.0522 \\
\hline No. of firms & 132,659 & 202,528 & 132,659 & 202,528 \\
\hline \multicolumn{5}{|l|}{ Correlation (average wage, } \\
\hline SD of wage) $)^{b}$ & 0.7622 & 0.7856 & -0.0561 & -0.0515 \\
\hline
\end{tabular}

Note: $\mathrm{SD}=$ Standard deviation.

${ }^{\text {a }}$ Employed persons.

${ }^{\mathrm{b}}$ Firms, U.S. operations.

log points. Using an alternative measure of dispersion, the worker at the 90th percentile in 1998 has log wages that are about $200 \log$ points larger than those of the worker at the 10th percentile, and this pattern is relatively stable between the two periods.

The second panel, the firm-level analysis, ${ }^{6}$ permits the quantification of the between versus within variation in wage patterns, as it shows the aver-

6. A firm is included in the analysis if that firm had positive average month three ES-202 employment during the year of twenty-five or more. 
age wage and the variation in wages across firms. Note that the average wage in the average firm is lower than the average individual wage - reflecting the skewed size distribution of firms. In other words, although most workers work in large firms, most firms are small. Because small firms pay less than large, a wage distribution based on firms as the unit of analysis will inevitably have a lower mean than one with individuals as the unit.

As with the individual analysis, it is clear that the entire distribution has shifted to the right during the period in question. In addition, the standard deviation of log wages between firms is large — about $50 \log$ points in 1993 and 1998. The 90-10 differential between firms is also large-around 130 $\log$ points. Although this is substantially less than the standard deviations associated with the individual distribution, it is clear that one of the key patterns for understanding the structure of wages is the earnings differences across firms.

The third issue is examining the within-firm wage dispersion, which is presented in the third panel. This shows tremendous variation in the dispersion of log wages within firms. Using as the metric the within-firm standard deviation of wages, the third panel shows that the mean standard deviation within firms is around 60 log points, or about three-fourths of the individual earnings distribution. ${ }^{7}$ Those firms with the least compressed distribution, those at the 90th percentile, have a standard deviation of 80 $\log$ points, and even in those firms with quite compressed earnings distribution, namely those at the 10th percentile of firms, the within-firm standard deviation is about $40 \log$ points. Interestingly, the distribution of standard deviations also shifted to the right (albeit slightly) during the period.

The fourth panel, which performs the same analysis for a different statistic, the average coefficients of variation across firms, shows similar patterns in terms of the earnings distribution. However, the dispersion of earnings relative to the mean wage is remarkably high: the standard deviation of earnings is about 75 percent of the mean wage. Even for the most compressed firms (the 10th percentile), the standard deviation is about 40 percent of the mean wage; for the least compressed, (the 90th percentile), it is a startling 120 percent.

Both of these panels make it clear that there is substantial within-firm variation at all points of the distribution and that this variation is a sizable fraction of individual variation. As a result, understanding within-firm dispersion in wages is likely to be an important component to understanding the individual earnings distribution. The large spread of earnings within firms is also consistent with the popularly held notion that the spread between top and bottom earnings within a U.S. firm is substantially greater than in their European counterparts.

7. Some caution must be used in comparing average standard deviation within firms to overall standard deviation across individuals because the average standard deviation within firms is not employment-weighted across firms. 
At the very bottom of table 2.3 is the simple statistic showing the correlation between the within-firm standard deviation of wages and the average wages of the firm. In dollars, the correlation is positive, but this reflects scale effects on the standard deviation measured in dollars. When wages are measured in logs, the correlation is slightly negative and essentially zero. Thus, for the entire United States there is little systematic relationship between within-firm dispersion of wages and average wages. This pattern is likely sensitive to industry and occupation. For example, in a study of the software industry and software engineers and managers, Andersson, Holzer, and Lane (2005) find a positive relationship between within-firm dispersion of earnings and average earnings. However, as argued in the latter paper, this pattern reflects the "winner take all" product mixes in some parts of the software industry such as in computer games.

The fact that the data are linked longitudinally at the individual level permits an analysis of wage dynamics by examining changes in the wage rate and changes in the log wage rate. ${ }^{8} \mathrm{~A}$ set of summary statistics is presented in table 2.4 .

An examination of the individual earnings distribution in the first panel reveals that the typical wage change in 1993 was negative and in 1998 positive. This result is consistent with the macroeconomic environment in both periods, as the former is likely to reflect recessionary pressures, while the later expansionary pressures. It is noteworthy that many workers did get sizable raises even in the recessionary periods, as the order of magnitude of the dispersion of wage changes is quite large - about $50 \mathrm{log}$ points - and the order of magnitude did not change much in the expansion. This finding is consistent with the notion that macroeconomic conditions affect the level but not the distribution of wage changes.

The wage growth distribution is quite remarkable. An analysis of this distribution shows that even when economic activity is strong, as in 1998, a substantial portion of the population actually experienced quite substantial earnings declines. Indeed, even at the 25 th percentile, log earnings declined by 6 points, and at the 10th percentile, log earnings declined by a startling 38 points. At the top end of the distribution, earnings increased by as much as 50 percent. In keeping with this finding, the standard deviation is quite large - about $50 \log$ points.

The fact that the linked employer-employee data are also linked longitudinally at the firm level enables us to calculate the change in mean firm log wages. An analysis of the results of this calculation, which are presented in the second panel, mirrors the individual distribution in that the mean log wage of firms actually declined in the first period and increased in the

8. An individual is included in the analysis if that person had a dominant employer in 1992 and 1993 or 1997 and 1998 and worked full time in both years. A firm is included in the analysis if that firm had positive average month three ES-202 employment during the year of twenty-five or more. 


\begin{tabular}{|c|c|c|c|c|}
\hline & \multicolumn{2}{|c|}{$\begin{array}{l}\text { Change in monthly } \\
\text { full-time wages }\end{array}$} & \multicolumn{2}{|c|}{$\begin{array}{c}\text { Change in } \\
\text { log monthly wages }\end{array}$} \\
\hline & 1993 & 1998 & 1993 & 1998 \\
\hline Average change in wage ${ }^{a}$ & -18 & 152 & -0.0039 & 0.0496 \\
\hline $\mathrm{SD}$ & 2,844 & 3,041 & 0.467 & 0.511 \\
\hline 90th percentile & 837 & 1,120 & 0.362 & 0.495 \\
\hline 75th percentile & 262 & 408 & 0.106 & 0.17 \\
\hline 25 th percentile & -231 & -144 & -0.093 & -0.064 \\
\hline 10th percentile & -869 & -784 & -0.386 & -0.379 \\
\hline No. of workers & $17,614,249$ & $35,607,319$ & $17,614,249$ & $35,607,319$ \\
\hline \multicolumn{5}{|l|}{ Average of firm average } \\
\hline change in wage ${ }^{\mathrm{b}}$ & -1 & 166 & -0.0017 & 0.0558 \\
\hline SD & 991 & 1,109 & 0.183 & 0.191 \\
\hline 90th percentile & 426 & 675 & 0.1404 & 0.2153 \\
\hline 75th percentile & 152 & 300 & 0.0661 & 0.1261 \\
\hline 25 th percentile & -191 & -92 & -0.0641 & -0.0181 \\
\hline 10th percentile & -459 & -337 & -0.1567 & -0.1124 \\
\hline No. of firms & 106,732 & 202,335 & 106,732 & 202,335 \\
\hline \multicolumn{5}{|l|}{ Average of SD of change } \\
\hline in wage ${ }^{b}$ & 1,621 & 1,782 & 0.4462 & 0.4917 \\
\hline $\mathrm{SD}$ & 1,858 & 2,021 & 0.202 & 0.206 \\
\hline 90th percentile & 3,192 & 3,625 & 0.707 & 0.7554 \\
\hline 75 th percentile & 1,836 & 1,993 & 0.5504 & 0.6012 \\
\hline 25 th percentile & 675 & 738 & 0.3072 & 0.3499 \\
\hline 10th percentile & 442 & 496 & 0.2255 & 0.2623 \\
\hline No. of firms & 106,732 & 202,335 & 106,732 & 202,335 \\
\hline \multicolumn{5}{|l|}{$\begin{array}{l}\text { Average coefficient of } \\
\text { variation of change }\end{array}$} \\
\hline in wages ${ }^{\mathrm{b}}$ & 2.50 & 2.49 & $-1.3944 \mathrm{E}+12$ & $9.15283 \mathrm{E}+12$ \\
\hline $\mathrm{SD}$ & 40.69 & 105.29 & $1.2939 \mathrm{E}+15$ & $3.6786 \mathrm{E}+15$ \\
\hline 90th percentile & 15.55 & 15.19 & 16.561 & 14.4548 \\
\hline 75th percentile & 5.72 & 6.3 & 6.2325 & 6.18 \\
\hline 25 th percentile & -6.36 & -4.64 & -5.6833 & -2.8749 \\
\hline 10th percentile & -15.91 & -13.83 & -15.9834 & -11.4428 \\
\hline No. of firms & 106,732 & 202,335 & 106,732 & 202,335 \\
\hline \multicolumn{5}{|l|}{$\begin{array}{l}\text { Average change in wage } \\
\text { for people who }\end{array}$} \\
\hline change firms ${ }^{\mathrm{a}}$ & -9 & 195 & 0.0243 & 0.1031 \\
\hline $\mathrm{SD}$ & 3,506 & 3,664 & 0.789 & 0.786 \\
\hline 90th percentile & 1,660 & 1,880 & 0.918 & 0.997 \\
\hline 75 th percentile & 666 & 805 & 0.391 & 0.46 \\
\hline 25 th percentile & -548 & -394 & -0.327 & -0.238 \\
\hline 10th percentile & $-1,716$ & $-1,460$ & -0.895 & -0.799 \\
\hline No. of workers & $3,718,398$ & $10,522,612$ & $3,718,398$ & $10,522,612$ \\
\hline
\end{tabular}

Notes: $\mathrm{SD}=$ Standard deviation. Percentiles for individuals were computed without using person weights due to computer memory limitations. Change in monthly wages is defined as wage in year $t$ - (wage in year $t-1$ ). Change in log monthly wages is defined as log wage in year $t-(\log$ wage in year $t-1)$.

${ }^{\text {a }}$ Employed persons.

${ }^{\mathrm{b}}$ Firms, U.S. operations. 
second. ${ }^{9}$ Just as in the individual distribution, there are substantial differences across firms: more than 25 percent of firms actually decreased their mean log wage in both periods, and there were large changes in mean log wages for some firms in both periods. Indeed, the 90th percentile firm actually increased mean $\log$ wages by $14 \log$ points in the first and by more than $21 \log$ points in the second period. The summary standard deviation statistics shows that between firm dispersion in log wage changes is around $19 \log$ points.

Because the data are linked longitudinally in both firms and workers, we can also calculate the distribution of the change in log wages for workers within each firm and calculate the standard deviation of this statistic. We provide summary information about the distribution of the standard deviation of this measure of the within-firm wage dispersion in panel three. What is especially striking is the large within-firm dispersion in wage changes. On average, within-firm dispersion in wage changes is $45 \mathrm{log}$ points in 1993 and 49 log points in 1998. In other words, some workers are doing much better within firms than others in terms of wage growth. Even in firms that kept the spread of their wage changes relatively compressed (the 10th percentile), the standard deviation was $20 \log$ points; at the other end of the distribution (the 90th percentile), the standard deviation was a substantial $70 \log$ points. The fourth panel, which reports a similar measure of spread - the coefficient of variation, reflects the same basic facts.

The last panel of table 2.3 sheds light on the structure of wage changes for those who changed firms. In contrast to the distribution of individuals as a whole, on average, the wage change is positive, especially in 1998, suggesting that the average worker gained from job change. However, the dispersion in wage changes is very large across those who changed firms, and clearly some workers lose substantially. At the 90th percentile, the average wage change is almost $100 \log$ points in 1998, while at the 10th percentile it is about $-80 \log$ points.

The counterpart of the analysis of wage changes within and across firms is clearly an analysis of mobility, and the results of just such an analysis are presented in table 2.5. We find a very high pace of accessions and separations..$^{10}$ We also find that workers are much more mobile at bottom end of distribution than at top - both in 1993 and 1998. Interestingly, despite the differences in macroeconomic activity in both periods, both entry and exit rates increased in 1998.

9. Of course, it remains an open question how much of this change is due to changes in wages for continuing workers and how much is due to changes in the workforce at the firm.

10. These rates are averages across firms and have not been employment-weighted, so they are somewhat larger than analogous accession and separation rates that are employmentweighted. In addition, these measures of worker turnover are higher than measures that use point in time changes or only count transitions for workers with some minimum duration of employment. There is an implicit duration requirement in that average real monthly earnings must exceed $\$ 100$ for a worker to be counted in these statistics, but this might still include a substantial number of short duration jobs. 
Table 2.5 Mobility (all jobs)

\begin{tabular}{lcc}
\hline & All firms with 25+ employees & \\
\hline & 1993 & 1998 \\
\hline Employees & 150 & 156 \\
Employment growth & $(782)$ & $(817)$ \\
& 0.14 & 0.17 \\
Exit (separation) rate & $(0.48)$ & $(0.49)$ \\
& 0.36 & 0.40 \\
Top quartile of firm wages & $(0.24)$ & $(0.24)$ \\
& 0.28 & 0.31 \\
Bottom quartile of firm wages & $(0.27)$ & $(0.28)$ \\
& 0.49 & 0.53 \\
Top decile of firm wages & $(0.27)$ & $(0.26)$ \\
& 0.28 & 0.30 \\
Bottom decile of firm wages & $(0.32)$ & $(0.32)$ \\
& 0.57 & 0.61 \\
Entry (accession) rate & $(0.31)$ & $(0.30)$ \\
& 0.27 & 0.34 \\
Top quartile of firm wages & $(0.24)$ & $(0.24)$ \\
& 0.20 & 0.26 \\
Bottom quartile of firm wages & $(0.26)$ & $(0.27)$ \\
Top decile of firm wages & 0.36 & 0.45 \\
& $(0.27)$ & $(0.26)$ \\
Bottom decile of firm wages & 0.19 & 0.24 \\
No. of firms (sum of weights) & $(0.29)$ & $(0.32)$ \\
\hline
\end{tabular}

Note: Numbers in parentheses are standard deviations.

\subsection{Summary}

This chapter has provided an initial examination of the earnings distribution both within and between firms at two different points of the business cycle. There is enormous variation in earnings across workers in the United States. A decomposition into the factors underlying this dispersion suggests that about half of the variation is associated with worker characteristics and about half due to firm effects. Thus, both who you are and where you work are very important in the determination of earnings. While there is substantial between firm variation in earnings, the within-firm variation of earnings is very large in terms of both levels and changes of earnings over time. So while where you work matters substantially, there is enormous variation in earnings within where you work as well. Accompanying the substantial between- and within-firm variation in earnings levels and changes is a high pace of worker turnover. The earnings dynamics and turnover are not surprisingly connected with workers that change jobs hav- 
ing on average a positive increase in earnings. However, underlying this positive average is substantial variation with the 25 th percentile of job changers exhibiting over a 20 percent decline in earnings and the 75 th percentile exhibiting a 40 percent increase in earnings. Putting all the pieces together suggests a rich and continuous ongoing matching and sorting of heterogeneous firms and workers with a wide variation in outcomes in the U.S. labor market.

\section{Appendix A}

\section{Summary of U.S. Statistics Measurement}

The nature of administrative data means that a number of technical issues arise in the creation of measures that are sensible for economic analysis. There is extensive documentation on the LEHD Web site (http:// lehd.ces.census.gov) on the characteristics of the data and the methods used to standardize information from different states. What follows is a brief summary of the approach used to prepare the data for this chapter.

Data from seven states are used in this analysis: California, Florida, Illinois, Maryland, Minnesota, North Carolina, and Texas, comprising about 40 percent of U.S. employment. The employer is the dominant employer in a given year (although multistate employment is not eliminated for a given year).

The earnings data are from quarterly UI wage records from each participating state. Unemployment insurance wage records measure "gross wages and salaries, bonuses, stock options, tips, and other gratuities, and the value of meals and lodging, where supplied" (Bureau of Labor Statistics 1997, 44). They do not include OASDI, health insurance, workers compensation, unemployment insurance, and private pension and welfare funds.

The following steps are taken in creating the earnings measures used in this chapter. First, earnings are converted to real earnings using the CPI. They are then annualized using the approach described in Abowd, Lengermann, and McKinney (2002) and converted to monthly earnings by dividing annualized earnings by 12 . Workers are included in analysis if real monthly earnings exceed $\$ 100$ and are less than $\$ 100,000$.

The unit of observation for the firm is the state unemployment insurance account number (SEIN). For single-unit establishment firms, the SEIN defines both the establishment and the firm. For multiple establishment firms, the SEIN typically includes all establishments within the state that are owned by this firm. For firms that operate in multiple states, the SEIN does not capture all activities of the firm but rather the operations for the state 
in question. Firms are included in the analysis if employment is larger than twenty-five.

National person and firm weights have been developed for the U.S. statistics in a manner described in appendix B.

Worker flows are calculated as follows. Entry (accession) and exit (separation) rates reflect links across years for jobs, where the unit of observation is defined as an individual-SEIN year observations (persons linked to a SEIN in a given year). Entry refers to workers who have zero earnings with SEIN in prior year $(t-1)$ and have positive earnings in current year $(t)$. Workers are only counted for purposes of computing rates if they satisfy above earnings thresholds. ${ }^{11}$ Exit refers to workers who have positive earnings in year $t$ at SEIN and zero earnings in year $t+1$. Workers are counted for purposes of computing rates if they satisfy above earnings thresholds. ${ }^{12}$ There is an important timing difference - entry refers to flow into firm from $t-1$ to $t$; exit refers to flow out of firm from $t$ to $t+1$. It is thus inappropriate to compute net flows from entry and exit.

Employment measures-average employment and employment growth - are based on Quarterly Census of Employment and Wages (QCEW) $202^{13}$ employment from the third month of each quarter. Average employment is computed as the average across the four quarters of the third month QCEW/202 employment measure. Net growth across years is based on the difference between the average value in time $t$ and $t+1$.

\section{Appendix B}

\section{The Construction of the National Weights}

\section{Person Level}

The control source is the final individual weights from the March Current Population Survey (CPS). The population was defined as those eighteenseventy-year-olds who were part of the employed, domestic, civilian noninstitutional population (ESR $=1$ or 2), age eighteen-seventy-year-olds (inclusive). The major industry classifications were the twenty-two CPS major industry categories. In constructing the weights, we used five age categories (eighteen to twenty-four, twenty-five to thirty-four, thirty-five to fortyfour, forty-five to fifty-four, fifty-five to seventy), three education categories

11. Note, however, that a worker who has positive earnings in year $t-1$ and $t$, but whose earnings fail to meet the threshold for inclusion in our analyses, is not counted as an entrant in $t$.

12. Similarly, a worker who has positive earnings in both year $t-1$ and $t$, but whose earnings fail to meet the threshold for inclusion, is not counted as an exit in $t$.

13. QCEW/202 employment is the number of workers on the payroll for the payroll period including the 12 th of the month. 
(zero to eleven years, exactly twelve years (completed), more than twelve years), and two sex categories (male, female).

For each year and major industry, we computed the expected number of employed persons inside each education $x$ age $x$ sex cell based on a loglinear probability model with three-way interactions suppressed estimated from the final weighted March CPS Annual Demographic Supplements (public use files). This is the weight numerator.

For each year and major industry, we computed the number of persons in each education $\times$ age $\times$ sex cell from the LEHD sample. ${ }^{14}$ This is the weight denominator.

The $P$-weight used is the ratio of the weight numerator to the weight denominator. $P$-weight thus performs a poststratification of the state-specific sample to 600 employment cells each year. The weighted person-level data are representative of the employed civilian noninstitutional population in each year.

The variable $P$-weight was used to weight all person-level estimates. For changes, the $t$ period and not the $t-1$ period weights were used.

\section{Firm Level}

The employment measure used was the average month three employment from the QCEW for every quarter that the SEIN had data in a given year. The control source was the Current Employment Statistics national estimates for two-digit Standard Industrial Classifications (SICs). The population used was all nonfarm establishments, with the following exceptions. The SICs for which the LEHD sample was not representative (SICs $01,02,08,43$ ) were excluded by means of assigning missing weights. Certain SICs were pooled (SICs 20-21, 71-72, 88-89, 90-99). Public administration (90-99) was estimated from federal, state, and local government employment exclusive of government-owned establishments in United States Postal Service (USPS), health, education, and social services, which were either excluded (USPS) or included in the correct SIC.

The numerator of the weight was calculated for each year and two-digit SIC from the total average annual employment from the national Current Employment Statistics (CES) series.

The denominator of the weight was calculated for each year and SEIN in the LEHD sample from total employment in the same two-digit SICs. Note that there are no empty cells and the exclusions noted in the preceding take care of industries in which the sample is probably not representative.

$F$-weight is the ratio of the weight numerator to the weight denominator. The $f$-weight is a poststratification of the LEHD sample to two-digit SIC

14. There are no empty cells. 
average annual employment in the CES. This $f$-weight is used to weight all firm-level statistics in the tables.

\section{References}

Abowd, John M., Francis Kramarz, and David N. Margolis. 1999. High wage workers and high wage firms. Econometrica 67:251-333.

Abowd, John M., Paul Lengermann, and Kevin McKinney. 2002. The measurement of human capital in the U.S. Economy. LEHD Technical Paper no. TP-2002-09. Washington, DC: U.S. Census Bureau, Longitudinal Employer-Household Dynamics. http://lehd.dsd.census.gov/led/library/techpapers/tp-2002-09.pdf.

Abowd, John M., Bryce Stephens, and Lars Vilhuber. Forthcoming. The LEHD infrastructure files and the creation of the quarterly workforce indicators. In Producer dynamics: New evidence from micro data, ed. T. Dunne, J. B. Jensen, and M. J. Roberts. Chicago: University of Chicago Press.

Abowd, John M., and Lars Vilhuber. 2005. The sensitivity of economic statistics to coding errors in personal identifiers. Journal of Business and Economics Statistics 23 (2) 133-52.

Acemoglu, Daron. 2002. Technical change, inequality, and the labor market. Journal of Economic Literature 40 (1): 7-72.

Andersson, Fredrik, Harry Holzer, and Julia Lane. 2005. Moving up or moving on: Who advances in the low-wage labor market? New York: Russell Sage Foundation.

Beaudry, Paul, and David A. Green. 2003. Wages and employment in the United States and Germany: What explains the differences? American Economic Review 93 (3): 573-602.

Bernard, Andrew B. and J. Bradford Jensen. 1998. Understanding Increasing and Decreasing Wage Inequality," Unpublished paper (Yale University).

Blackburn, McKinley L., David E. Bloom, and Richard B. Freeman. 1990. The declining position of less-skilled American males. In A future of lousy jobs?, ed. by G. Burtless, 31-67. Washington, DC: Brookings Institution.

Bureau of Labor Statistics. 1997. Handbook of methods. Washington, DC: U.S. Department of Labor, Office of Publications and Special Studies. http://www.bls.gov/ opub/hom/home.htm.

Burgess, Simon, Julia Lane, and David Stevens. 2000. Job flows and worker flows in the life cycle of the firm. Oxford Bulletin of Economics and Statistics 62:885-908.

Burtless, Gary. 1990. Earnings inequality over the business and demographic cycles. In A future of lousy jobs?, ed. by G. Burtless, 77-122. Washington, DC: Brookings Institution.

Card, David, and John DiNardo. 2002. Skill-biased technological change and rising wage inequality: Some problems and puzzles. Journal of Labor Economics 20 (4): 733-83.

Card, David, Francis Kramarz, and Thomas Lemieux. 1999. Changes in the relative structure of wages and employment: A comparison of the United States, Canada, and France. Canadian Journal of Economics 32 (4): 843-77.

Congressional Budget Office. 2005. The role of immigrants in the U.S. labor market. http://www.cbo.gov/ftpdocs/68xx/doc6853/11-10-Immigration.pdf.

Davis, Steven J., R. Jason Faberman, and John Haltiwanger. 2006. The flow approach to labor markets, micro-macro links, and the recent downturn. Journal of Economic Perspectives 20 (3): 3-26. 
Davis, Steven J., and John Haltiwanger. 1991. Wage dispersion within and between manufacturing plants. Brookings Papers on Economic Activity, Microeconomics: $115-80$.

1996. Employer size and the wage structure in U.S. manufacturing. Annales D'Economie et de Statistique (41-42):323-68.

DiNardo, John, Nicole Fortin, and Thomas Lemieux. 1996. Labor market institutions and the distribution of wages, 1973-1992. Econometrica 64:1001-4.

Groshen, Erica. 1991. Sources of intra-industry wage dispersion: How much do employers matter? Quarterly Journal of Economics 106 (3): 869-84.

Juhn, Chinhui, and Simon Potter. 2006. Changes in labor force participation in the United States. Journal of Economic Perspective 20 (3): 27-46.

Katz, Lawrence, and David Autor. 1999. Changes in the wage structure and earnings inequality. In Handbook of labor economics. Vol. 3, ed. O. Ashenfelter and D. Card, 1463-1555. Amsterdam: North-Holland.

Lee, David S. 1999. Wage inequality in the United States during the 1980s: Rising dispersion or falling minimum wage. Quarterly Journal of Economics 114:9771023.

Lemieux, Thomas. 2004. Residual wage inequality: A reexamination. University of British Columbia, Working Paper.

Levy, F., and R. J. Murnane. 1992. U.S. earnings levels and earnings inequality: A review of recent trends and proposed explanations. Journal of Economic Literature 30:1333-81.

Moffitt, Robert. 1990. The distribution of earnings and the welfare state. In $A f u$ ture of lousy jobs?, ed. by G. Burtless, 201-35. Washington, DC: Brookings Institution.

Stevens, David W. 2002. Employment that is not covered by state unemployment insurance laws. LEHD Technical Paper no. TP-2002-16. Washington, DC: U.S. Census Bureau, Longitudinal Employer-Household Dynamics. 